\title{
Construction and Application of Customer Satisfaction Model with the Service Quality of Last-Mile Delivery in Rural Areas
}

\author{
YUH- JEN CHO ${ }^{1 \mathrm{a}}$, LIN XUE ${ }^{2 *}$, SHU-RONG HUANG ${ }^{3 \mathrm{~b}}, \mathrm{ZHE}^{\mathrm{P}}$-PENG YANG ${ }^{3 \mathrm{c}}$ \\ ${ }^{1}$ Department of Transportation Technology and Logistics Management, Chung Hua University \\ Hsinchu, Taiwan, CHINA \\ ${ }^{2} \mathrm{Ph} . \mathrm{D}$. Program of Technology Management, Chung Hua University \\ Hsinchu, Taiwan, CHINA \\ ${ }^{2,3}$ Economics and Management School, Minjiang University \\ Fuzhou, CHINA
}

\begin{abstract}
The backward last-mile delivery infrastructures, the greater difficulties in last-mile delivery due to the scattered residences of rural customers and the lack of logistics professionals in rural areas have emerged as the important factors hindering the improvement of the service quality of last-mile delivery in rural areas. This study combines the classic satisfaction index model and transformation of the SERVQUAL standard scale to draw up the connotations and observation variables of customer expectations, quality perception, perceived value, customer satisfaction, customer complaints and customer loyalty with the service quality of last-mile delivery in rural areas, and takes 460 permanent residents in rural areas as the research objects, then constructs and tests the customer satisfaction model of the service quality of last-mile delivery in rural areas, and deeply analyzes the relationship between customer satisfaction and its influencing factors; by constructing a twodimensional combination potential of entropy weight-satisfaction average value, the in-depth application of the model is discussed, and at the same time, it provides policy suggestions for local governments, logistics companies and other entities to improve the customer satisfaction with the service quality of last-mile delivery in rural areas.
\end{abstract}

Key-Words: - Last-mile delivery in rural areas, Customer satisfaction, Structural equation model, Twodimensional combination potential

Received: November 18, 2020. Revised: March 23, 2021. Accepted: April 3, 2021. Published: April 12, 2021.

\section{Introduction}

With the surge in the number of online shoppers in rural areas, precise last-mile delivery has become a hot topic drawing broad public attention. The service quality of last-mile delivery in rural areas refers to the extent to which logistics companies leverage their lastmile delivery resources (i.e., the product mix consisting of tangible products and intangible services) to meet the explicit or implicit needs of online shoppers in rural areas. It depends largely on the demand side's perception of delivery service at the "real moment" of service contact. Specifically, tangible products include service environment and goods, i.e., the supporting facilities and equipment necessary for service provision, and the goods purchased by the online shoppers in rural areas, while intangible services cover non-quantitative implicit factors such as the confidentiality of personal information, the service attitude of deliverymen, and the quality of complaint handling. The online shoppers in rural areas are the main customers of logistics companies' last-mile delivery service, and hence their perceived value of the service process and service outcome has emerged as a crucial consideration amid the management innovation of logistics companies.

\section{Research Summary}

\subsection{Research on the Influencing Factors of Customer Satisfaction in Logistics Services}

The academic circles generally believe that the quality of logistics services is a factor that affects their satisfaction, and to a certain extent determines the probability of customers' second choice of services. Hashank R. et al. combined the file data of 260 online retailers and found that in the service quality dimension of logistics, customer satisfaction with logistics quality and cost is directly proportional to their purchase satisfaction and customer retention rate 
[1]; Yang, H. et al. found that the core service quality and remedial service quality will have a positive and significant impact on customer satisfaction in the logistics service process [2]; Zuoliang $\mathrm{Ye}$ et al. believed that logistics interaction and operation quality will affect customer satisfaction with third-party logistics service providers, thereby affecting customer satisfaction with enterprises [3]; Yaozi $\mathrm{He}$ et al. divided the factors that affect the quality of logistics services into information capabilities, distribution capabilities, pre-sales and after-sales services, matching capabilities, and innovation capabilities, through empirical analysis, the above factors have a significant impact on customer satisfaction [4]; Combining the structural equation model, Wensheng Ma established a research model on the relationship between service quality and customer satisfaction in the logistics industry. The results show that the five dimensions of logistics service quality, such as tangibility and reliability, have a positive and significant impact on customer satisfaction [5].

\subsection{Research on the Measurement and Evaluation of Logistics Service Quality}

Foreign research on the measurement and evaluation of logistics service quality is relatively rich, and is mostly based on the perspective of enterprises and customers. Among them, the more classic measurement and evaluation models include: the PDSQ (physical distribution service quality) scale developed by Mentzer extracted three main dimensions of timeliness, availability, and quality from 26 specific items [6]; after that they introduced personnel, process factors and innovatively established the LSQ scale including nine dimensions covering information quality, order release quantity, time, communication quality, etc. and a total of 25 evaluation items [7]; later, Bienstock et al. conducted an empirical test on the PDSQ scale, and improved the new PDSQ scale which increased the measurement items of intangible services accepted by customers [8].

Domestic scholars have also proposed evaluation or measurement indicators of logistics service quality from different research perspectives. Jian $\mathrm{Xu}$ et al. comprehensively used Analytic Hierarchy Process, SEVEQUAL and other methods to construct a logistics enterprise service quality evaluation index system from the three perspectives of enterprise service performance, service process, and service capability [9]; Yaoli Zhang combined small-scale B2C and $\mathrm{C} 2 \mathrm{C}$ online shopping, used process analysis to find out 38 contact points with customers in their logistics services, and then distributed questionnaires to small merchants with signing experience, six representative factors that affect the quality of online shopping logistics services are sorted out, including delivery service level, order-taking service level, ability to fulfill orders correctly, timeliness, information service capacity and price [10]; Fang Lu used empirical research and analysis to regard availability, utility, and interactivity as the three most important dimensions of logistics service quality [11].

The above studies provided useful ideas for the research on the customer satisfaction with the service quality of last-mile delivery in rural areas, but there are still some shortcomings: firstly, the research on ecommerce logistics and distribution in rural areas is still at the stage of preliminary discussion, and related research is mainly limited to the difficulty of logistics distribution and countermeasures; there are few studies on the evaluation index system to measure the quality of last-mile delivery in rural areas, some studies also directly used the results of previous studies, the established index system generally has the characteristics of being too complicated and poor in practicability, moreover, it mostly focused on singleindex simple weighting processing, lacking a multiindex linkage measurement system, and seldom used certain evaluation methods to conduct comprehensive evaluation research. Secondly, related satisfaction surveys only focused on the comparison of results and cause analysis, and didn't provide methods for how to use the survey results; there is little research on the relationship between variables and the evolutionary law, and it is impossible to intuitively understand the causal relationship between variables, the lack of verification of the rationality of the model leads to poor effectiveness of the research results.

Based on the analysis of the current status of lastmile delivery in rural areas, this study takes the rural online shopping consumer groups in Fujian Province as the research object, and uses the structural equation modeling method to design a customer satisfaction model of the service quality of last-mile delivery in rural areas, and empirically analyzed the relationship between customer satisfaction and its influencing factors; a two-dimensional combination potential of entropy weight-satisfaction average value was constructed to deepen the application of the satisfaction model; finally, it provides policy recommendations for local governments, logistics companies and other multi-agents to improve the customer satisfaction with the service quality of lastmile delivery in rural areas.

\section{Status of Last-Mile Delivery in Rural Areas}

\subsection{Backward Last-mile Infrastructures in Rural Areas}

Delivery 
The infrastructures in rural areas lag far behind those in urban areas, especially the transportation infrastructures. The narrow and rugged roads in some rural areas make it difficult for vehicles to pass through, and hence a well-functioning transportation network cannot be formed, not to mention door-todoor delivery. Rural customers sometimes have to pick up the goods purchased online at the package pickup point, the fact of which greatly hampers the enthusiasm of rural customers to shop online and compromises the safety and timeliness of the goods purchased online [12].

\subsection{Greater Difficulties in Last-mile Delivery Due to the Scattered Residences of Customers}

The vast population and scattered residences in rural areas have brought about two major challenges to lastmile delivery: 1) it's difficult to plan consistent delivery routes, making delivery time-consuming and labor-intensive; and 2) the costs of delivery remains high as the number of packages to be delivered to rural customers is still at a low level.

\subsection{Lack of Logistics Professionals in Rural Areas}

In rural areas, a large number of young people have left home to work in cities, therefore leading to a severe shortage of qualified logistics professionals and making it difficult to carry out effective last-mile delivery.

Taking the online shoppers in the rural areas of Fujian Province as the research subjects, this study uses the structural equation modeling (SEM) to design a customer satisfaction model for measuring the service quality of last-mile delivery in rural areas, and empirically analyzes the relationships between the satisfaction of online shoppers in rural areas and satisfaction-affecting factors, thereby informing efforts made by logistics companies to build an efficient lastmile delivery system.

\section{Research Hypotheses and Model Establishment}

\subsection{Initial Model and Research Hypothesis}

Building upon the American Customer Satisfaction Index (ASCI), this study has designed a customer satisfaction model for measuring the service quality of last-mile delivery in rural areas. This model takes the expectations of rural customers, quality perceived by rural customers and value perceived by rural customers as the premise latent variables, and takes customer satisfaction, customer complaints and customer loyalty are the result latent variables. The initial model and research hypotheses are shown in Figure 1 and Table 1 .

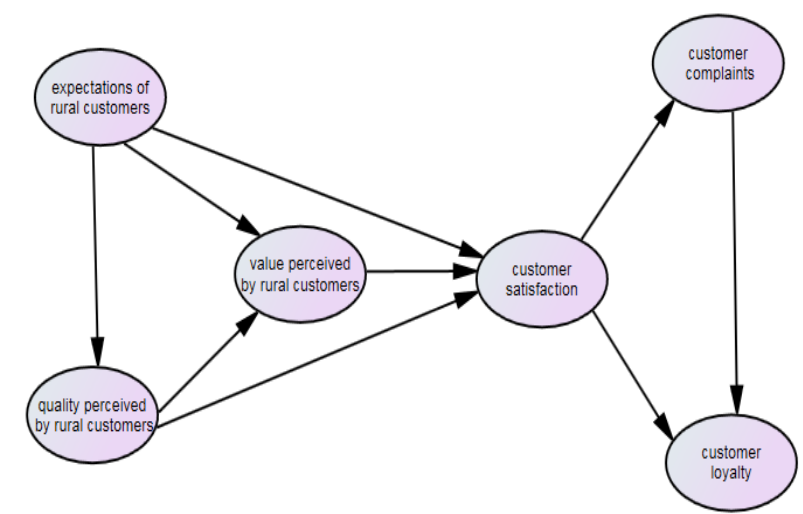

Fig.1 Initial customer satisfaction model for measuring the service quality of last-mile delivery in rural areas

Table 1. Research hypotheses for the initial model

\begin{tabular}{cc}
\hline SN & Research Hypotheses \\
\hline H1 & $\begin{array}{c}\text { Customer expectations have a positive } \\
\text { impact on customer satisfaction }\end{array}$ \\
\hline H2 & $\begin{array}{c}\text { Customer perceived quality has a positive } \\
\text { impact on customer satisfaction }\end{array}$ \\
\hline H3 & $\begin{array}{c}\text { Customer perceived value has a positive } \\
\text { impact on customer satisfaction }\end{array}$ \\
\hline H4 & $\begin{array}{c}\text { Customer expectations has a positive impact } \\
\text { on customer perceived value }\end{array}$ \\
\hline H5 & $\begin{array}{c}\text { Customer perceived quality has a positive } \\
\text { impact on customer perceived value }\end{array}$ \\
\hline H6 & $\begin{array}{c}\text { Customer perceived value plays a mediator } \\
\text { role between customer expectations and } \\
\text { customer satisfaction }\end{array}$ \\
\hline H7 & $\begin{array}{c}\text { Customer perceived value plays a mediator } \\
\text { role between customer perceived quality and } \\
\text { customer satisfaction }\end{array}$ \\
\hline H8 & $\begin{array}{c}\text { Customer satisfaction has a positive impact } \\
\text { on customer complaints }\end{array}$ \\
\hline H9 & $\begin{array}{c}\text { Customer satisfaction has a positive impact } \\
\text { on customer loyalty }\end{array}$ \\
\hline H10 & $\begin{array}{c}\text { Customer complaints has a positive impact } \\
\text { on customer loyalty }\end{array}$ \\
\hline
\end{tabular}

\subsection{Variables}

Based on the results of existing foreign studies and the results of empirical research relating to other industries, this study identified the connotations of the latent variables in the initial model. Among them, customer expectations refer to the expectations that customers have before accepting the last-mile delivery service; customer perceived quality refers to the actual feelings of customers after receiving the last-mile delivery service, and can be measured from five aspects with the aid of SERVQUAL scale, this study uses the entropy weight method (EWM) to calculate the weights of the corresponding items and the scores 
for tangibles, reliability, responsiveness, assurance, and empathy [13]. The customer perceived value can be measured by the gap between the expected service quality and the perceived service quality [14]. Customer satisfaction is directly affected by customer expectations and the degree to which they are satisfied [15]. Customer satisfaction could help reduce customer complaints, customers often express their complaints through formal complaints and informal complaints that influence the choices of others [16]. As a combination of customers' awareness and behavior, customer loyalty can be measured from two aspects: intention to recommend and intention to purchase again [17], satisfied customers would make a long-term purchase commitment to a certain brand or company. The latent variables are measured by the liker 5-level scoring method, as shown in Table 2.

Table 2. Connotations of latent variables and observable variables in the model

\section{Latent \\ Variables \\ Observable Variables}

1.You expect the courier company to provide a service that makes you very satisfied (X1)

2.You expect the delivery service of the courier company to be fast and timely (X2)

3.You expect the delivery service of the

Customer courier company to be precise (X3)

expectations 4.You expect the courier company to F1 ensure that the goods are delivered in good condition (X4)

5.You expect that the courier company could keep providing higher quality lastmile delivery service and become an industry model (X5)

6.You expect a more convenient way of package pickup (X6)

\begin{tabular}{|c|c|}
\hline $\begin{array}{l}\text { Customer } \\
\text { perceived } \\
\text { quality } \\
\text { F2 }\end{array}$ & $\begin{array}{l}\text { 7. Tangibles [X7] } \\
\text { 8. Reliability [X8] } \\
\text { 9. Responsiveness [X9] } \\
\text { 10. Assurance (X10) } \\
\text { 11. Empathy [X11] } \\
\end{array}$ \\
\hline $\begin{array}{l}\text { Customer } \\
\text { perceived } \\
\text { value } \\
\text { F3 }\end{array}$ & $\begin{array}{l}\text { 12.The delivery service is worth its } \\
\text { corresponding price (X12) } \\
\text { 13.Customers' time and mental costs } \\
\text { (X13) }\end{array}$ \\
\hline $\begin{array}{c}\text { Customer } \\
\text { satisfaction } \\
\text { F4 }\end{array}$ & $\begin{array}{l}\text { 14.How satisfied are you with the } \\
\text { delivery service of the courier company } \\
\text { (X14) } \\
\text { 15.To what extent can the delivery } \\
\text { service of the courier company meet } \\
\text { your expectations (X15) }\end{array}$ \\
\hline $\begin{array}{l}\text { Customer } \\
\text { complaints }\end{array}$ & $\begin{array}{l}\text { 16.Cost-effectiveness of the last-mile } \\
\text { delivery service (X16) }\end{array}$ \\
\hline
\end{tabular}

\begin{tabular}{|c|c|}
\hline F5 & $\begin{array}{l}\text { 17.Satisfaction with dispute handling } \\
\text { (X17) }\end{array}$ \\
\hline \multirow{4}{*}{$\begin{array}{c}\text { Customer } \\
\text { loyalty } \\
\text { F6 }\end{array}$} & 18. Possibility of choosing again (X18) \\
\hline & $\begin{array}{l}\text { 19.Possibility of recommending to } \\
\text { others (X19) }\end{array}$ \\
\hline & 20. Acceptable price increase (X20) \\
\hline & $\begin{array}{l}\text { 21.Possibility of long-term cooperation } \\
\text { (X21) }\end{array}$ \\
\hline
\end{tabular}

\subsection{Questionnaire}

This study takes permanent rural residents with online shopping experience in Fujian Province as the research subjects. The questionnaires distributed to these research subjects consist of two parts: 1) basic personal information, including gender, age, monthly frequency of online shopping, etc.; and 2) items related to the 6 latent variables and scored using the 5-point Likert scale. The specific items were designed with reference to previous research and the SERVQUAL scale, as shown in Table 3 through Table 8 [18].

Table 3. Items related to the latent variable of customer expectations

\begin{tabular}{|c|c|}
\hline Q5 & $\begin{array}{c}\text { You expect the courier company to } \\
\text { provide a service that makes you very } \\
\text { satisfied }\end{array}$ \\
\hline Q6 & $\begin{array}{l}\text { You expect the delivery service of the } \\
\text { courier company to be fast and timely }\end{array}$ \\
\hline Q7 & $\begin{array}{l}\text { You expect the delivery service of the } \\
\text { courier company to be precise }\end{array}$ \\
\hline Q8 & $\begin{array}{l}\text { You expect the courier company to } \\
\text { ensure that the goods are delivered in } \\
\text { good condition }\end{array}$ \\
\hline Q9 & $\begin{array}{l}\text { You expect that the courier company } \\
\text { could keep providing higher quality last- } \\
\text { mile delivery service and become an } \\
\text { industry model }\end{array}$ \\
\hline Q10 & $\begin{array}{l}\text { You expect a more convenient way of } \\
\text { package pickup }\end{array}$ \\
\hline
\end{tabular}

Table 4. Items related to the latent variable of customer perceived quality

\begin{tabular}{|c|c|c|c|}
\hline Variables & & Items & Weight \\
\hline \multirow{4}{*}{ Tangibles } & Q11 & $\begin{array}{l}\text { The basic service } \\
\text { facilities at the } \\
\text { package pickup point } \\
\text { are complete }\end{array}$ & 0.099 \\
\hline & Q12 & $\begin{array}{l}\text { The deliverymen } \\
\text { have neat clothing } \\
\text { and appearance }\end{array}$ & 0.143 \\
\hline & Q13 & $\begin{array}{l}\text { It's easy to pick up } \\
\text { the package from } \\
\text { where you live }\end{array}$ & 0.291 \\
\hline & Q14 & $\begin{array}{c}\text { The pickup points of } \\
\text { different courier }\end{array}$ & 0.217 \\
\hline
\end{tabular}




\begin{tabular}{|c|c|c|c|}
\hline & \multicolumn{3}{|c|}{$\begin{array}{l}\text { companies are close } \\
\text { to each other }\end{array}$} \\
\hline & Q15 & $\begin{array}{l}\text { No area is omitted by } \\
\text { the delivery service }\end{array}$ & 0.250 \\
\hline \multirow{7}{*}{ Reliability } & Q16 & $\begin{array}{l}\text { The goods delivered } \\
\text { by the courier } \\
\text { company are correct }\end{array}$ & 0.198 \\
\hline & Q17 & $\begin{array}{l}\text { There is no omission } \\
\text { of the goods } \\
\text { delivered by the } \\
\text { courier company }\end{array}$ & 0.131 \\
\hline & Q18 & $\begin{array}{c}\text { The delivery } \\
\text { destinations are } \\
\text { correct }\end{array}$ & 0.119 \\
\hline & Q19 & $\begin{array}{l}\text { The goods delivered } \\
\text { by the courier } \\
\text { company are in good } \\
\text { condition }\end{array}$ & 0.123 \\
\hline & Q20 & $\begin{array}{l}\text { The outer packaging } \\
\text { of the goods } \\
\text { delivered by the } \\
\text { courier company is } \\
\text { intact }\end{array}$ & 0.163 \\
\hline & Q21 & $\begin{array}{l}\text { The courier company } \\
\text { is reliable in delivery }\end{array}$ & 0.121 \\
\hline & Q22 & $\begin{array}{l}\text { The courier company } \\
\text { can deliver the goods } \\
\text { within the specified } \\
\text { time }\end{array}$ & 0.145 \\
\hline \multirow{3}{*}{$\begin{array}{l}\text { Responsiv } \\
\text { eness }\end{array}$} & Q23 & $\begin{array}{c}\text { The courier company } \\
\text { can provide real-time } \\
\text { information about my } \\
\text { packages }\end{array}$ & 0.239 \\
\hline & Q24 & $\begin{array}{l}\text { You expect the } \\
\text { courier company to } \\
\text { respond to your } \\
\text { complaints in time }\end{array}$ & 0.356 \\
\hline & Q25 & $\begin{array}{c}\text { The deliverymen } \\
\text { won't be too busy to } \\
\text { service your needs } \\
\text { immediately }\end{array}$ & 0.405 \\
\hline \multirow{3}{*}{ Assurance } & Q26 & $\begin{array}{l}\text { Deliverymen's } \\
\text { proficiency in } \\
\text { workflow }\end{array}$ & 0.287 \\
\hline & Q27 & $\begin{array}{c}\text { The confidentiality of } \\
\text { your personal } \\
\text { information during } \\
\text { the delivery process }\end{array}$ & 0.390 \\
\hline & Q28 & $\begin{array}{c}\text { The deliverymen are } \\
\text { very polite }\end{array}$ & 0.323 \\
\hline Empathy & Q29 & $\begin{array}{l}\text { The deliverymen can } \\
\text { promptly } \\
\text { communicate with } \\
\text { you on the status of } \\
\text { the goods being }\end{array}$ & 1.000 \\
\hline
\end{tabular}

delivered

Table 5. Items related to the latent variable of perceived value

\begin{tabular}{cc}
\hline Q30 & $\begin{array}{c}\text { The delivery service is worth its } \\
\text { corresponding price }\end{array}$ \\
\hline Q31 & $\begin{array}{c}\text { Less time and mental costs in } \\
\text { handling the logistics formalities }\end{array}$ \\
\hline
\end{tabular}

Table 6. Items related to the latent variable of customer satisfaction

\begin{tabular}{cc}
\hline Q32 & $\begin{array}{c}\text { How satisfied are you with the delivery service } \\
\text { of the courier company }\end{array}$ \\
\hline Q33 & $\begin{array}{c}\text { To what extent can the delivery service of the } \\
\text { courier company meet your expectations }\end{array}$ \\
\hline
\end{tabular}

Table 7. Items related to the latent variable of customer complaints

\begin{tabular}{lc}
\hline Q34 & $\begin{array}{c}\text { Cost-effectiveness of the last-mile delivery } \\
\text { service }\end{array}$ \\
\hline Q35 & $\begin{array}{c}\text { Your satisfaction with the courier company's } \\
\text { handling of disputes }\end{array}$ \\
\hline
\end{tabular}

Table 8. Items related to the latent variable of customer loyalty

\begin{tabular}{lc}
\hline Q36 & Possibility of choosing again \\
\hline Q37 & Possibility of recommending to others \\
\hline Q38 & Acceptable price increase \\
\hline Q39 & Possibility of long-term cooperation \\
\hline
\end{tabular}

\section{Discussion}

\subsection{Reliability Test of the Model}

A total of 541 questionnaires were distributed to permanent residents in rural areas and 460 valid questionnaires were recovered. SPSS 20.0 was used to find that the Cronbach's Alpha coefficient of the reliability subscale of each latent variable in the questionnaire was above 0.7 , and that the Cronbach's Alpha coefficient of the whole scale reached 0.968, indicating that this scale is highly reliable. Therefore, the 6 latent variables and 21 observable variables in the initial model $\mathrm{M}_{1}$ were retained [19].

\subsection{Model Testing and Adjustment}

AMOS 7.0 was used to test and correct the initial model $\mathrm{M}_{1}$ (Figure 2), with significance test results of relevant parameters shown in Table 9. When the corresponding $\mathrm{P}$ values are all greater than 0.1 , it's deemed that the corresponding path coefficients are not significantly different from zero at $90 \%$ confidence. Therefore, the four paths of $\mathrm{F} 1 \rightarrow \mathrm{F} 3$, $\mathrm{F} 1 \rightarrow \mathrm{F} 4, \mathrm{~F} 2 \rightarrow \mathrm{F} 4$ and $\mathrm{F} 5 \rightarrow \mathrm{F} 6$ are removed. By further 
adjusting and simplifying model $\mathbf{M}_{1}$, model $\mathbf{M}_{2}$ was obtained, as shown in Figure 3.

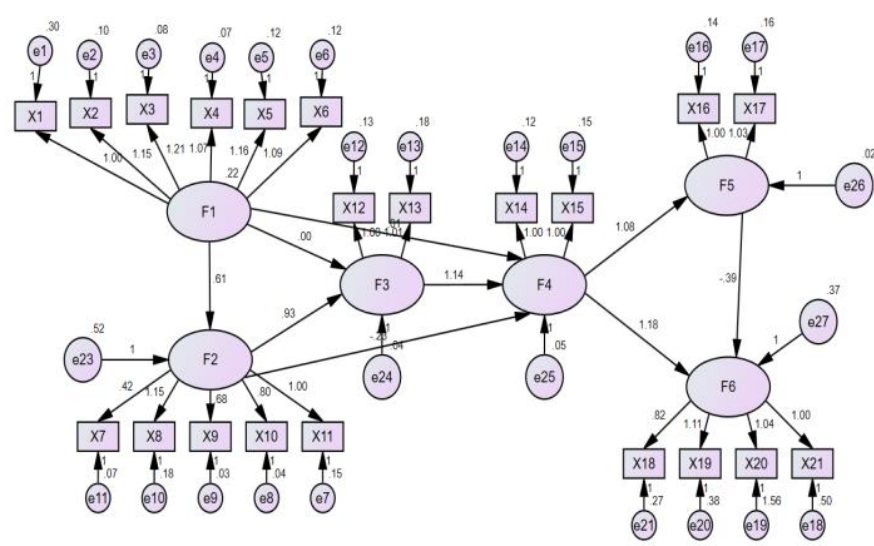

Fig.2 Coefficient estimation and test results of model $\mathrm{M}_{1}$

Table 9. Parameter significance test results of model $\mathrm{M}_{1}$

\begin{tabular}{cccc}
\hline $\begin{array}{c}\text { Variable } \\
\text { path }\end{array}$ & Estimate & C.R. & $\mathrm{P}$ \\
\hline $\mathrm{F} 1 \rightarrow \mathrm{F} 2$ & 0.609 & 7.204 & $* * *$ \\
\hline $\mathrm{F} 2 \rightarrow \mathrm{F} 3$ & 0.931 & 26.608 & $* * *$ \\
\hline $\mathrm{F} 1 \rightarrow \mathrm{F} 3$ & 0.003 & 0.066 & 0.947 \\
\hline $\mathrm{F} 3 \rightarrow \mathrm{F} 4$ & 1.141 & 3.973 & $* * *$ \\
\hline $\mathrm{F} 1 \rightarrow \mathrm{F} 4$ & 0.010 & 0.201 & 0.841 \\
\hline $\mathrm{F} 2 \rightarrow \mathrm{F} 4$ & -0.226 & -0.838 & 0.402 \\
\hline $\mathrm{F} 4 \rightarrow \mathrm{F} 5$ & 1.075 & 28.907 & $* * *$ \\
\hline $\mathrm{F} 4 \rightarrow \mathrm{F} 6$ & 1.184 & 1.733 & 0.083 \\
\hline $\mathrm{F} 5 \rightarrow \mathrm{F} 6$ & -0.393 & -0.630 & 0.529 \\
\hline
\end{tabular}

Testing the goodness-of-fit of model $\mathrm{M}_{2}$ : As shown in Table 10, among the absolute fit, incremental fit and parsimonious fit indices of model $\mathrm{M}_{2}$, more than half of the indices fit, indicating good overall fitness and pointing to the fact that the optimized model $\mathrm{M}_{2}$ is a better one [20].

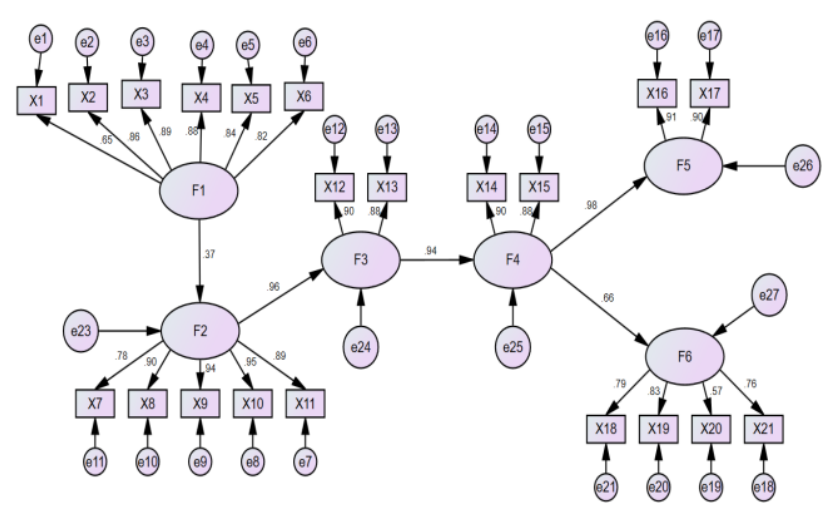

Fig.3 Coefficient estimation and test results of optimized model $\mathrm{M}_{2}$

Table 10. Fit indices for the optimized model

\begin{tabular}{cccc}
\hline $\begin{array}{c}\text { Statistical } \\
\text { test }\end{array}$ & $\begin{array}{c}\text { Fitting } \\
\text { criteria or } \\
\text { thresholds }\end{array}$ & Test results & $\begin{array}{c}\text { Goodness } \\
\text { of Fit }\end{array}$ \\
\hline Absolute Fit Indices & & \\
\hline $\begin{array}{c}\text { CMIN } \\
\text { /DF }\end{array}$ & $\begin{array}{c}\text { P>0.05 (not } \\
\text { up to the } \\
\text { significant } \\
\text { level) }\end{array}$ & $\begin{array}{c}2.785 \\
(\mathrm{P}=0.000)\end{array}$ & $\begin{array}{c}\text { Reference } \\
\text { index }\end{array}$ \\
\hline RMR & $<0.05$ & 0.038 & Yes \\
\hline RMSEA & $<0.08$ & 0.062 & Yes \\
\hline SRMR & $<0.05$ & 0.0511 & No \\
\hline GFI & $>0.9$ & 0.904 & Yes \\
\hline AGFI & $>0.9$ & 0.88 & No \\
\hline CN & $>200$ & 512.36 & Yes \\
\hline Incremental Fit Indices & & \\
\hline NFI & $>0.95$ & 0.946 & No \\
\hline RFI & $>0.90$ & 0.938 & Yes \\
\hline IFI & $>0.95$ & 0.965 & Yes \\
\hline TLI & $>0.95$ & 0.960 & Yes \\
\hline CFI & $>0.95$ & 0.965 & Yes \\
\hline Parsimonious Fit Indices & & \\
\hline PNFI & $>0.50$ & 0.829 & Yes \\
\hline PCFI & $>0.50$ & 0.845 & Yes \\
\hline & & &
\end{tabular}

\subsection{Empirical Result Analysis and Inspiration}

The relationships and the interactions between factors affecting customer satisfaction with the service quality of last-mile delivery in rural areas can be observed via the changes in the standardized path coefficients of each variable in the optimized model $\mathbf{M}_{2}$, as shown in Table 11.

Firstly, it can be seen from the results of significance that the research hypotheses $\mathrm{H} 1, \mathrm{H} 2$, and H4 are not valid, and other hypotheses are supported, that is, the direct paths from customer expectations and customer perceived quality to customer satisfaction is not significant, and the path from customer expectations to customer perceived value is not significant. The path coefficients of "customer expectation", "customer perceived quality" and "perceived value" on "customer satisfaction" are 0.332, 0.902 and 0.938 , which reflect the influence of various factors influencing customer satisfaction with the service quality of last-Mile delivery in rural areas to a certain extent. Among them, "perceived value" has the greatest impact. As the scale of online shopping in rural areas continues to expand, the number of logistics services contacted by rural customers has also continued to increase, they have long-term and stable expectations for the basic service quality of various express logistics companies. In the environment of increasingly fierce competition in logistics services, it is not obvious that logistics companies expect to 
improve customer satisfaction by adjusting customer expectations, They should pay more attention to the stable output of service quality, allow customers to produce more accurate expectations, gradually narrow the gap between expected quality and perceived quality, and pay attention to changes in the price of logistics services and the spiritual cost of customers waiting for logistics procedures to improve perception value, then improve customer satisfaction.

Secondly, by further analyzing the effect of customer perceived quality on customer satisfaction, it can be seen that there are gaps between the indirect effects of the five elements of customer perceived quality on customer satisfaction. Specifically, the indirect effects of tangibles, reliability, responsiveness, assurance and empathy transmitted to customer satisfaction through customer perceived value are 0.71 , $0.81,0.85,0.86$ and 0.81 respectively, indicating that among the elements of customer perceived quality that affect customer satisfaction, assurance has the strongest indirect effect, while intangibles have the weakest indirect effect. Based on the questionnaire items, in the case of limited resource input, adopting a differentiation strategy based on the development characteristics of the five dimensions will be an important way for local governments, logistics companies and other participating entities to improve the quality of customer perception.

For example, in terms of logistics talent supply, local governments should introduce relevant policies to attract highly educated talents to join the rural logistics and distribution industry; logistics companies should regularly train their deliverymen, place emphasis on reflections, improvements and skills updates, and test the competency of deliverymen through irregular assessments, so as to build a professional service team and provide customers with outstanding services. By narrowing the gap between service commitments and realities, as well as between the perceived quality and the expected quality, the logistics companies will be able to effectively improve the satisfaction of online shoppers in rural areas. in terms of advancing infrastructure construction, local governments should take the initiative to invest in the construction of distribution resources, which can be leased for use by logistics enterprises; logistics companies should make full use of social logistics resources in all aspects of rural distribution, such as using public transportation resources as transportation tools and public facilities resources as distribution nodes. Logistics companies can share distribution resources to reduce the idleness of logistics resources and improve the economic benefits of rural distribution.

Finally, in terms of the post-factors of customer satisfaction, "customer satisfaction" has a significant positive impact on "customer loyalty". From the customer's point of view, they only need to be satisfied with this logistics service, but from the perspective of logistics companies, "customer satisfaction" is not enough, what the company needs is "customer loyalty", and satisfaction must be transformed. From the perspective of the path coefficient, the impact of "customer satisfaction" on "customer loyalty" is as high as 0.663 , and customer satisfaction is the main influencing factor of customer loyalty.

Table 11. The direct effect, indirect effect and total effect among the latent variables in the model (standardized results)

\begin{tabular}{ccccc}
\hline & F1 & F2 & F3 & F4 \\
\hline F2 & $0.368^{* * *}$ & - & - & - \\
\hline $\begin{array}{c}\text { (Direct } \\
\text { effect) }\end{array}$ & $(7.24)$ & - & - & - \\
\hline $\begin{array}{c}\text { Indirect } \\
\text { effect) }\end{array}$ & - & - & - & - \\
\hline $\begin{array}{c}\text { (Total } \\
\text { effect) }\end{array}$ & 0.368 & - & - & - \\
\hline F3 & - & $0.961^{* * *}$ & - & - \\
\hline $\begin{array}{c}\text { (Direct } \\
\text { effect) }\end{array}$ & - & $(27.55)$ & - & - \\
\hline $\begin{array}{c}\text { Indirect } \\
\text { effect) }\end{array}$ & 0.354 & - & - & - \\
\hline $\begin{array}{c}\text { (Total } \\
\text { effect) }\end{array}$ & 0.354 & 0.961 & - & - \\
\hline
\end{tabular}

\begin{tabular}{ccccc} 
effect) & & - & $0.938^{* * *}$ & - \\
\hline F4 & - & - & $(26.33)$ & - \\
\hline $\begin{array}{l}\text { Direct } \\
\text { effect) }\end{array}$ & - & - &
\end{tabular}

\begin{tabular}{ccccc}
\hline $\begin{array}{c}\text { (Indirect } \\
\text { effect) }\end{array}$ & 0.332 & 0.902 & - & - \\
\hline $\begin{array}{c}\text { (Total } \\
\text { effect) }\end{array}$ & 0.332 & 0.902 & 0.938 & - \\
\hline
\end{tabular}

\begin{tabular}{ccccc}
\hline F6 & - & - & - & $0.663^{* * *}$ \\
\hline $\begin{array}{c}\text { (Direct } \\
\text { effect) }\end{array}$ & - & - & - & $(12.94)$ \\
\hline $\begin{array}{c}\text { (Indirect } \\
\text { effect) }\end{array}$ & 0.22 & 0.598 & 0.622 & - \\
\hline $\begin{array}{c}\text { (Total } \\
\text { effect) }\end{array}$ & 0.22 & 0.598 & 0.622 & 0.663 \\
\hline F5 & - & - & - & $0.981^{* * *}$ \\
\hline $\begin{array}{c}\text { (Direct } \\
\text { effect) }\end{array}$ & - & - & - & $(28.90)$ \\
\hline $\begin{array}{c}\text { (Total } \\
\text { effect) }\end{array}$ & 0.325 & 0.885 & 0.920 & 0.981 \\
\hline
\end{tabular}

Note: "***" means it's significant at the level of 0.01 . The figure in brackets refers to the corresponding C.R. value ( $t$ value). The parameters given in the table are all standardized parameters, and the direct effect is the path coefficient in the model. 


\subsection{Deepening Application of the Two- dimensional Combination Potential of Entropy Weight-Satisfaction Average Value}

In order to enhance the application effect of the comprehensive evaluation model of customer satisfaction, this study adopts K-means clustering algorithm to cluster the satisfaction average value and entropy weighting result of the evaluation variables of customer perceived quality, and divides them into two regional levels. The average value of satisfaction is taken as the horizontal axis, the entropy weight is taken as the vertical axis, and the horizontal and vertical axes intersect at $(4.14,0.07)$, the plane is divided into four quadrants. According to the different characteristics of the quadrants, the analysis matrix is divided into four types of potential regions. Local governments, logistics companies and other entities should adopt differentiated development models and strategies for service elements in different quadrants. The details are shown in Figure 4.

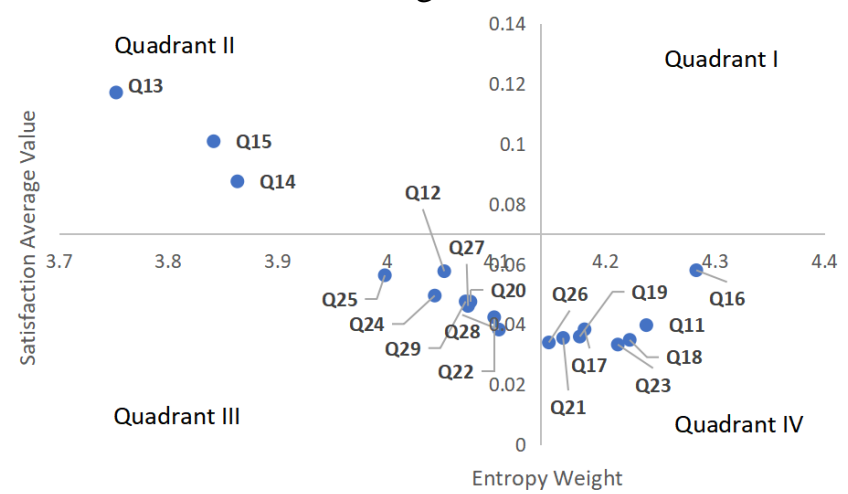

Fig.4 Diagram on the two-dimensional combination potential of entropy weight-satisfaction average value

Quadrant I is the continued maintenance area characterized by high relevance and high importance. Currently, no service elements have fallen into this zone. Quadrant II is a key area for improvement characterized by low relevance and high importance covering three service elements of Q13, Q14 and Q15, the degree of customer satisfaction with its service and the importance of the index are in an imbalanced state; regarding the service elements in this area, relevant entities should adopt the strategy of "active connection and priority improvement", and appropriately tilt resources to speed up the improvement of the service quality of the area elements to meet customer needs. Quadrant III is a low priority area characterized by low relevance and low importance, covering 8 service elements including Q12, Q20, Q22, Q24, Q25, Q27, Q28, and Q29. In the case of limited resources, relevant entities should adopt the strategy of "continuous attention and key breakthrough" for the service elements in the region, and pay attention to the changes in customer expectations for indicators in the region, prioritize the development of system function enhancement projects with great resource potential, and break the low degree of relevance in order to produce breakthrough effects. Quadrant IV is an intensive development area characterized by high relevance, low importance, and covering the remaining service elements. It has obvious oversupply phenomenon, but it is also an important factor affecting the popularity and brand of distribution services. For the service elements in this area, relevant entities should adopt the strategy of "integrate innovation and transfer resource" to gradually improve the resource allocation efficiency of the elements in the area, and on the basis of maintaining the overall strength of services, timely referral of some resources to the service elements of Quadrant II.

\section{Conclusion}

The value judgment of rural netizens on the process of last-mile delivery service in rural areas and the degree of achievement of the result goal has become an important link in the management innovation of the government, logistics enterprises and other entities to improve the quality of terminal distribution service.

Firstly, This study draws on the ASCI and SERVQUAL standard scale to design the customer satisfaction model with the service quality of last-Mile delivery in rural areas taking the expectations of rural customers, quality perceived by rural customers and value perceived by rural customers as the premise latent variables, and taking customer satisfaction, customer complaints and customer loyalty are the result latent variables. It takes 460 permanent residents in rural areas as the research objects, then constructs and tests the customer satisfaction model and deeply analyzes the relationship between customer satisfaction and its influencing factors. Empirical results showed: there are different key factors affecting the customer satisfaction with the service quality of last-mile delivery in rural areas. Among the premise factors of customer expectations, customer perceived quality and customer perceived value, customer expectations have an indirect effect on customer satisfaction through customer perceived quality and perceived value, and there are gaps between the indirect effects of the five elements of customer perceived quality on customer satisfaction, with assurance having the strongest indirect effect and intangibles having the weakest indirect effect. customer satisfaction is the main influencing factor of customer loyalty.

Secondly, in the case of limited resource input, adopting differentiated strategies based on the development characteristics of the five dimensions will be an important way for local governments, logistics companies and other entities to improve the customer perceived quality, customer satisfaction and customer loyalty. Local government and logistics companies can gradually improve customer satisfaction with the service 
quality of last-mile delivery services in rural areas by catering to the actual needs of rural customers, revving up infrastructure construction, ensuring the confidentiality of customer information, further improving and optimizing the delivery routes, strengthening the training of employees, and improving the professional services of delivery.

Finally, in order to enhance the application effect of the satisfaction model, multi-agents should adopt differentiated development models and strategies for the characteristics of quality perception service elements in different combination potential areas, including continued maintenance areas, improved key areas, lower priority areas, and intensive development areas.

\section{Acknowledgment}

The research is supported by the Minjiang University Principal Fund Project in 2021.

\section{Author contribution}

Yuh- jen Cho conceived idea; Lin Xue performed the data analysis and wrote the paper; Shu-rong Huang and Zhe-peng Yang collected the data and revised the paper.

\section{References:}

[1] Hashank R., Thomas J. G., Stanley E. G., Deepak I., Electronic logistics service quality (e-LSQ): its impact on the customer's purchase satisfaction and retention. Journal of Business Logistics, Vol.32, No.2, 2011, pp.167-179.

[2] Yang,H., Tsai,F., General E-S-QUAL scales applied to websites satisfaction and loyalty model, Communications of the IIMA, Vol.7, No.2, 2007, pp.115.

[3] Zuoliang Ye, Li Cai, Zhenhua Ye, Li Dai, Third party logistics service quality and its impact on customer satisfaction of C2C, Science Research Management, Vol.32, No.8, 2011, pp.119-126.

[4] Yaoyu He, Yongwei Lv, The practical research on the influencing factors of logistic service quality and customer loyalty, China Business and Market, Vol.26, No.7, 2012, pp.79-82.

[5] Wenxing Ma, Study on relationship between service quality and customer satisfaction in logistics industry, Logistics Technology,Vol.33, No.4, 2014, pp.195-197.

[6] Mentzer, J. T. , Gomes, R. , Krapfel, R. E. , Physical distribution service: a fundamental marketing concept?, Journal of the Academy of Marketing Science, Vol.17, No.1, 1989, pp.53-62.
[7] Mentzer J T, Flint D J KENT J L, Developing a logistics service quality scal, Journal of Business Logistics,Vol.20, No.1, 1999, pp.9-32.

[8] Bienstock C C, Mwntzer T J, BIRD M M, Measuring physical distribution service quality, Journal of the Academy Marketing science,Vol.25, No.4, 1997, pp.31-44.

[9] Jian Xu, Junqiang Liu, Xiaochang Fang, Research on evaluation index system of service quality about logistics enterprise, Logistics Sci-Tech,Vol.29, No.1, 2006, pp.48-51.

[10] Yaoli Zhang, Guangying Xie, Jing Chen, The construction of evaluation index system of logistics service quality in online shopping with small b2c and $\mathrm{c} 2 \mathrm{c}$ as example, Journal of Anhui Agricultural Science, Vol.41, No.1, 2013, pp. 454-458.

[11] Fang Lu, Jinghuan Yang, Evaluation index system on logistics service quality of enterprise A, Journal of Hunan University of Commerce, Vol.23, No.2, 2016, pp. 56-63.

[12] Tao Chu, Weiqiang Jia, Development status and countermeasures of rural express logistics distribution, Journal of Nanchang Hangkong University (Social Science Edition), Vol.21, No.1, 2019, pp. 12-17.

[13] Parasuraman, A. , Zeithaml, V. A., Berry, L. L. , A conceptual model of service quality and its implication for future research (servqual), Journal of Marketing, Vol.49, No.4, 1985, pp. 41-50.

[14] Anderson, E. W. , Fornell, C., Foundations of the american customer satisfaction index, Total Quality Management, Vol.11, No.7, 2000, pp. S869-S882.

[15] Oliver, R. L., A cognitive model of the antecedents and consequences of satisfaction decisions, Journal of Marketing Research, Vol.17, No.4, 1980, pp. 460-469.

[16] Anderson, E. W. , Fornell, C., Lehmann, D. R., Customer satisfaction, market share, and profitability: findings from sweden, Journal of Marketing, Vol.58, No.3, 1994, pp.53-66.

[17] Jianping Huang, Jinming $\mathrm{Li}$, On satisfaction and loyalty of customers, Journal of Beijing Technology and Business University(social science), Vol.18, No.4, 2003, pp.35-39.

[18] Changcheng Liu ,Lin Xue, Improving Paths of Student Satisfaction Education Services in Newly-Established Universities_-Taking Minjiang University as an Example, Journal of Minjiang University, Vol.37, No.1, 2016, pp.112-119.

[19] Hongdan Zhao, Zhenglong Peng, Dong Liang, Relationship of organizational trust, employment relationship and knowledge sharing, Journal of management sciences, Vol.23, No.6, 2011, pp.33-42.

[20] Zixiang $\mathrm{Hu}$, The Construction and Confirmatory Analysis of Mean Structure Model of Service Quality in Higher Education, Fudan education forum, Vol.9, No.3, 2011, pp. 27-32.

\section{Creative Commons Attribution License 4.0 (Attribution 4.0 International, CC BY 4.0)}

This article is published under the terms of the Creative Commons Attribution License 4.0 https://creativecommons.org/licenses/by/4.0/deed.en_US 